Dampak Media Sosial... (Anik Suryaningsih)

\title{
DAMPAK MEDIA SOSIAL TERHADAP PRESTASI BELAJAR PESERTA DIDIK
}

\author{
Oleh : Anik Suryaningsih \\ (Fakultas Keguruan Ilmu Pendidikan, UKSW Salatiga) \\ e-mail: anik.yaning99@gmail.com
}

\begin{abstract}
Abstrak
Media Sosial merupakan alat komunikasi atau informasi yang memungkinkan penggunanya dapat melakukan percakapan, bertukar informasi atau menuangkan ide. Namun media sosial ini malah menjadi momok yang sangat menakutkan bagi beberapa peserta didik, apalagi mereka yang menyalahgunakan media sosial bukan untuk kepentingan belajar. Media sosial sangat berpengaruh sekali bagi peserta didik umtuk menunjang prestasi belajar. Prestasi belajar adalah sebuah hasil belajar dari yang dicapai setelah mengikuti proses kegiatan pembelajaran. Prestasi belajar pun dapat ditunjukkan dalam bentuk angka atau nilai, untuk memperoleh tercapainya prestasi belajar diperlukannya sebuah usaha yang maksimal. Apalagi di dalam kegiatan belajar mengajar diperlukan suatu proses mengatur, mengorganisasi lingkungan yang ada di sekitar peserta didik sehingga dapat menumbuhkan dan mendorong peserta didik melakukan proses belajar. Peran orang tua dan para guru di sekolah sangat diharapkan untuk membantu peserta didik dalam membatasi diri dalam media sosial. Tujuan penulis menuliskan ini adalah untuk mengetahui pengaruh : (1) prestasi belajar; (2) media sosial; (3) dampak negatif dan dampak positif; (4) peran guru di sekolah terhadap dampak penggunaan media sosial.
\end{abstract}

Kata Kunci: Dampak, Media Sosial, Prestasi Belajar

\section{THE IMPACT OF SOCIAL MEDIA ON LEARNING ACHIEVEMENTS LEARNERS}

\begin{abstract}
Social media not for learning purposes. Social media is very influential for students to support learning achievement. Learning achievement is a result of learning achieved after participating in the process of learning activities. Learning achievements can also be shown in the form of numbers or values, to obtain the achievement of learning achievement requires a maximum effort. Moreover, in teaching and learning activities a process of organizing, organizing the environment around students is needed so that it can foster and encourage students to do the learning process. The role of parents and teachers in schools is expected to help students in limiting themselves in social media. The purpose of the author to write this is to determine the effect of: (1) learning achievement; (2) Social Media; (3) effect negative and positive; (4) the role of teachers in schools on the impact of the use of social media.
\end{abstract}

Keyword: Effect, Sosial Media, Learning Achievement 


\section{A. PENDAhuluan}

Di era globalisasi sekarang ini perkembangan ilmu pengetahuan dan teknologi semakin canggih, penyebaran informasi yang begitu cepat dan akses telekomunikasi yang semakin mudah dapat dijumpai di beberapa media social seperti youtube, instagram, facebook, whats app, google, wikipedia. Teknologi komunikasi mutakhir telah menciptakan apa yang disebut "publik dunia" atau "weltonffentlichkeit". Dengan begitu perkembangan teknologi komunikasi ini menjadi meningkat dan menimbulkan kecemasan mengenai efek media sosial yang ditimbulkan terhadap khalayak umum (Najamudin, 2019).

Di dalam perkembangan media sosial, pendidikan di Indonesia pun juga ikut berkembang dan dampaknya sekarang banyak kegiatan aktivitas pendidikan melibatkan media sosial. Dari pusat menuju ke setiap sekolah-sekolah banyak yang menggunakan sistem informasi online yang dapat diakses setiap penangung jawab yang menangani informasi lalu di sebarluaskan. Untuk media sosial saat ini sangatlah mudah dan dapat dijangkau siapapun, di manapun, dan kapanpun. Contohnya sekarang ini hampir semua alat komunikasi seperti handphone pun sudah memiliki aplikasi yang tentunya terdapat media sosial didalamnya yang memudahkan penggunanya untuk menjelajah internet (Permata, 2019).

Media sosial boleh diperkenankan untuk siswa apabila dapat digunakan untuk mencari informasi yang positif dan dapat bermanfaat dalam belajar, sekarang ini pun hampir seluruh siswa cendrerung menggunakan akses media sosial namun juga ada beberapa siswa yang menggunakan media sosial bukan untuk kebutuhan belajarnya tetapi malah mencari informasi yang lain. Dampak terburuk dalam dunia pendidikan yang mungkin dihasilkan dari media sosial adalah mulai menurunnya tingkat kesadaran siswa mengenai belajar dan mempengaruhi prestasi belajarnya. Prestasi belajar adalah sebuah hasil belajar dari yang tercapai setelah mengikuti proses kegiatan pembelajaran (Rahman, 2017).

Prestasi belajar pun dapat ditunjukan dalam bentuk angka atau nilai, untuk memperoleh tercapainya prestasi belajar diperlukannya sebuah usaha yang maksimal. Apalagi didalam kegiatan belajar mengajar diperlukan suatu proses 
mengatur, mengorganisasi lingkungan yang ada di sekitar peserta didik sehingga dapat menumbuhkan dan mendorong peserta didik melakukan proses belajar. Jika didalam pembelajaran siswa tidak dapat mengikutinya dengan baik dan tidak fokus, bagaimana tujuan pembelajaran dapat tercapai dan terealisasikan dengan baik.

Banyak masalah yang ditimbulkan apabila pesera didik menggunakannya baik dari media sosial dengan tidak baik dalam kehidupan nyata, apalagi dampaknya terhadap bidang pendidikan yakni siswa menjadi malas-malasan belajar, sering mengakses yang bukan untuk materi pembelajaran, apa yang dilihat dimedia sosial ditirukan dalam kehidupan sosialnya seperti sinetron, drama korea dan lain sebagainya, minat siswa untuk mengikuti pelajaran juga mengalami penurunan dari semua itu membuat prestasi belajar siswa menurun.

Berkurangnya waktu belajar yang dialami siswa itu sendiri karena terlalu sering menggunakan media sosial sehingga muncul rasa ingin tahu dan tidak pernah ketinggal menyelidiki dunia maya. Pada saat kegiatan pembelajaran berlangsung terdapat siswa cenderung berfikiran mengenai respon pengguna lainnya dalam sebuah status yang dituliskan di salah satu media sosial instagram ataupun facebook sehingga mengalami lambat belajar atau proses pembelajarannya dapat terhambat. Yang terjadi biasanya siswa sudah tidak lagi menyukai salah satu mata pelajaran sehingga membuat siswa tidak mau belajar dan cenderung memainkan media sosial untuk menghibur diri saat mengalami kegelisahan.

Apabila semua itu sudah terjadi dan siswa mengalami penurunan prestasi belajar dan membuatnya tidak menyesal kehidupannya pun tidak bisa jauh dari media sosial. Selain itu media sosial membuat siswa menjadi terpengaruh chattingan terus menerus, belum lagi kebiasaan menulis dibuku yang sangat malas dan tergantung pada gadget. Kebiasaan mengeluh yang selalu dituangkan dalam media sosial ingin selalu direspon dan diperhatikan entah itu kicauan tentang kehidupan sekolah, keluarga atau masyarakat. Kebiasaan siswa ini berbeda dengan siswa jaman dulu yang memiliki akses sosial yang masih minim. 
Berdasarkan uraian diatas, maka pengaruh media sosial bagi kalangan pelajar ada konsekuensinya. Salah satunya yaitu terhadap pembelajaran dan prestasi belajar siswa. Baik dan buruknya akan diperoleh dari apa yang dilakukan siswa tersebut. Oleh karena itu, dalam penelitian ini rumusan masalah yang diangkat adalah bagaimana dampak media sosial terhadap prestasi belajar peserta didik.

\section{B. METODOLOGI PENELITIAN}

Metode yang digunakan dalam artikel "Dampak Media Sosial Terhadap Prestasi Belajar Peserta Didik" menggunakan metode atau pendekatan kepustakaan. Menurut Zed (2003:3) studi pustaka atau kepustakaan dapat diartikan sebagai serangkaian kegiatan yang berkenaan dengan metode pengumpulan data dan pustaka, membaca dan mencatat serta mengolah bahan penelitian. Dalam penelitian pustaka ini dilakukan pengumpulan data dengan menelaah beberapa artikel-artikel secara online, buku, dokumen, serta sumbersumber data lainnya yang dianggap relevan dengan penelitian. Kata kunci yang digunakan peneliti dalam pengumpulan data adalah "Dampak Media Sosial terhadap Prestasi Belajar Peserta Didik".

Dari pengumpulan data tersebut diperoleh berbagai macam artikel, skripsi, tesis dan buku. Penelitian ini bersifat kualitatif yang lebih mengutamakan penggalian, penemuan, pembacaan, penjelasan dan penyampaian simbol data yang tersurat dan terserat dari data yang dikumpulkan. Analisis yang digunakan bersifat deskriptif, filosofis dan teoritis.

\section{HASIL PENELITIAN DAN PEMBAHASAN}

Media Sosial merupakan alat komunikasi atau informasi yang memungkinkan penggunanya dapat melakukan percakapan, bertukar informasi atau menuangkan ide dalam sebuah web. Namun media sosial masuk dalam kategori media siber yang apabila tidak menggunakan koneksi internet tidak dapat terhubung. Setiap tahun pengguna internet selalu mengalami kenaikan baik itu nasional maupun internasional. Dari kalangan pelajar pengguna media sosial juga 
banyak apalagi sekarang ini banyak anak muda yang tidak ingin ketinggalan jaman.

\section{Pengertian Dampak}

Dampak menurut kamus Besar Bahasa Indonesia yakni bentuk, pengaruh kuat yang dapat mendatangkan akibat baik maupun buruk atau dapat berarti benturan yang cukup hebat antara dua benda sehingga dapat menyebabkan perubahan yang terjadi di dalam kehidupan. Setiap individu bilamana saat membuat keputusan yang terja sudah dipikirkan secara matang-matang dan biasanya akan membawa dampak yang positif atau negatif. Dari beberapa penjabaran di atas dapat kita bagi menjadi dua pengertian:

\section{a. Pengertian Dampak Positif}

Pengertian dampak adalah sebuah kayakinan untuk mempengaruhi atau memberikan perubahan supaya dapat mengikuti alur jalannya. Sedangkan positif adalah sesuatu hal yang pasti dan dapat terurai dengan memperhatikan hal-hal yang baik. Didalam positif terdapat hasil perubahan yang membawa suasana jiwa yang tertuang didalam pelaksanaan kegiatan kegembiraan, optimis. Bagi individu yang mempunyai fikiran positif mengetahui bahwa dirinya dapat menangkal pikiran negative.

b. Pengertian Dampak Negatif

Dampak negative memiliki arti yang sangat kuat yaitu pengaruh yang membawa aura negative, dampak yakni suatu keyakinan untuk mempengaruhi seseorang tidak berbuat sesuai tujuan mereka atau menjauhi hal-hal yang baik. Hasil yang diperoleh dalam dampak negative tidak selalu mendatangkan suasana jiwa yang teruang dalam kehidupan menjadi nyaman dan tentram.

\section{Pengertian Media Sosial}

Media sosial adalah sebuah media online, dengan para penggunanya bisa dengan mudah berpartisipasi, berbagi, dan menciptakan isi meliputi blog, jejaring sosial, wiki, forum dan dunia virtual. Blog, jejaring sosial dan wiki merupakan bentuk media sosial yang paling umum digunakan oleh masyarakat di seluruh dunia. Pendapat lain mengatakan bahwa media sosial adalah media online yang 
mendukung interaksi sosial dan media sosial menggunakan teknologi berbasis web yang mengubah komunikasi menjadi dialog interaktif.

Andreas Kaplan dan Michael Haenlein mendefinisikan media sosial sebagai "sebuah kelompok aplikasi berbasis internet yang membangun di atas dasar ideologi dan teknologi Web 2.0, dan yang memungkinkan penciptaan dan pertukaran user-generated content". Berikut ini adalah definisi dari media sosial menurut beberapa ahli :

a. Menurut Mandibergh, media sosial adalah media yang mewadahi kerja sama di antara pengguna yang menghasilkan konten (user generated content).

b. Menurut Shirky, media sosial dan perangkat lunak sosial merupakan alat untuk meningkatkan kemampuan pengguna untuk berbagi (to share), bekerja sama (to co-operate) di antara pengguna dan melakukan tindakan secara kolektif yang semuanya berada di luar kerangka institusisional maupun organisasi.

c. Menurut Van Dijk, media sosial adalah platform media yang memfokuskan pada eksistensi pengguna yang memfasilitasi mereka dalam beraktivitas maupun berkolaborasi. Karena itu, media sosial dapat dilihat sebagai medium (fasilitator) online yang menguatkan hubungan antar pengguna sekaligus sebuah ikatan sosial.

Dari berbagai definisi tersebut, dapat diambil kesimpulan bahwa definisi media sosial adalah sebuah jejaring di internet yang memungkinkan penguna merepresentasikan dirinya maupun berinteraksi, bekerja sama, berbagi, berkomunikasi dengan pengguna lain, dan membentuk ikatan sosial atau suatu alat perantara yang digunakan untuk berinteraksi dan berkomunikasi antara seseorang dengan orang lain yang banyak memberikan kontribusi atau manfaat bagi masyarakat.

\section{Prestasi Belajar}

Prestasi Belajar merupakan prestasi itu hasil atau sesuatu yang telah di kerjakan melalui beberapa proses, sedangkan belajar merupakan perubahan tingkah laku dan pengalaman untuk memperoleh ilmu pengetahuan atau 
kepandaian (Laos, 2017). Prestasi belajar adalah sebuah hasil belajar dari yang dicapai setelah mengikuti proses kegiatan pembelajaran. Atau juga dapat diartikan serangkaian hasil usaha yang dapat ditunjukan dalam bentuk nilai atau tulisan yang terpenting dapat diukur.

Untuk memiliki prestasi belajar yang memuaskan diperlukannya usaha belajar. Belajar merupakan proses kegiatan usaha yang melibatkan siswa belajar sehingga suasana seperti peristiwa belajar dapat terjadi dengan seksama dan membawa perubahan tingkah laku dari siswa. Pembelajaran merupakan suatu langkah atau proses yang dilakukan pendidik dengan peserta didik melibatkan interaksi satu sama lain agar memperoleh ilmu, pengetahuan, dan pengalaman belajar serta pembentukan sikap kepada peserta didik.

Suatu proses kegiatan pembelajaran yang terjadi dikelas haruslah kondusif dan tenang. Suatu komponen yang dibutuhkan untuk mencapai sebuah tujuan dibutuhkan dukungan dari siswa dan semua anggota yang terlibat didalam sekolah. Di dalam pembelajaran juga diperlukan sebuah proses untuk mengatur, menata, mengorganisasi lingkungan yang terdapat di area peserta didik supaya terdorong dan terlibat dalam kegiatan proses pembelajaran. Tentunya segala aspek sangat diperlukan untuk memenuhi kebutuhan peserta didik. Saat kegiatan pembelajaran berlangsung pun terdapat beberapa perbedaan yang dialami oleh peserta didik dalam kemampuan mencerna materi pembelajaran yaitu dapat mencernanya dan mengaplikasikannya dalam kehidupan dan ada juga yang mengalami lambat belajar dalam menampung materi.

Di era Indonesia sekarang ini banyak peserta didik saat mendapatkan tugas dari guru menggunakan akses penuh media sosial dari internet, youtube sebagai sumber informasi belajar. Pembelajaran yang berkaitan dengan digital media sosial sangat membantu peserta didik dalam proses kegiatannya. Namun semua itu tergantung dari perilaku peserta didik, apakah mereka bisa membawa pengaruh media sosial kearah yang lebih baik atau malah membuatnya semakin jauh dari kata baik dan malah merugikan. 


\section{Dampak dari Media Sosial terhadap Prestasi Belajar}

Peserta didik yang selalu ingin mencari informasi untuk meningkatkan prestasi belajar adalah mereka yang mau berusaha dengan berbagai cara untuk mendapatkannya, yang terjadi sekarang ini sudah banyak peserta didik yang menggunakan media sosial untuk kebutuhan belajarnya tapi kalau dilihat lebih lanjut media sosial ini dapat membawa pengaruh yang positif dan pengaruh yang negatif terhadap prestasi belajar yang didapat peserta didik di sekolah (Fitri, 2017). Terdapat beberapa dampak yang diperoleh yaitu:

a. Dampak positif media sosial:

- Mempermudahkan proses pembelajaran, karena saat peserta didik mengalami kendala atau kesulitan didalam belajar dapat mengakses informasi dari media sosial dengan begitu akan meningkatkan prestasi belajarnya.

- Semakin mempermudah berinteraksi kepada orang lain, yaitu apabila peserta didik mengalami kendala dapat dengan mudah mengubungi gurunya atau orang lain untuk mendapatkan hasil belajar yang baik yang dapat menunjang presti belajarnya.

- Menambah wawasan, peserta didik yang dapat menggunakan media sosial dengan sangat bermanfaat akan mempermudah mengasah kemampuan mereka untuk menganalisis, mengakses berbagai informasi yang didapatkan kian meningkat seiring berjalannya waktu, sampai tidak dapat disadari mereka sudah mengembangkan kemampuan mereka.

- Mendukung untuk materi pembelajaran

Dapat membantu mengidentifikasi konten tambahan untuk memperluas materi yang berasal dari media sosial seperti youtube yang menyediakan video untuk memperjelas materi pembelajaran.

b. Dampak negatif

- Membuat kecanduan, tidak dapat dipungkiri bahwa para pengguna ini akan sulit lepas dari media sosial. Waktu yang begitu berharga hanya dihabiskan untuk menggunakan media sosial, terlebih lagi 
bagi kaum rebahan yang setiap harinya tidur dengan genggaman media sosial.

- Pornografi, apabila peserta didik sudah menggunakannya ke hal yang buruk akan berdampak pada belajarnya, lingkungan bermain dan juga sikap perilakunya. Apabila itu terjadi maka peserta didik akan sulit memahami materi yang diajarkan oleh guru, karena hanya memikirkan yang bukan materi.

- Malas-malasan, bagi pecandu akan berpengaruh terhadap kehidupan pribadinya misal disekolah mendapatkan tugas dari guru tidak langsung dikerjakan, dirumah pun menjadi malas untuk mengerjakan tugas sekolah alhasil medapatkan nilai merah dan prestasi disekolah menurun.

- Mengganggu konsentrasi belajar peserta didik saat disekolah, ketika dia sudah mulai bosan dengan penjelasan guru maka ia pun akan mengeluarkan handphone nya untuk bermain media sosial entah whats app, instagram, facebook dll.

Selain itu menurut John Nasavith menyebutkan bahwa kemajuan bidang teknologi seperti internet yang memuat media sosial dapat mempengaruhi perubahan tingkah laku peserta didik, bagi peserta didik yang ingin memiliki prestasi belajar yang baik dan meningkat supaya mengatur bagaimana caranya agar media sosial itu tidak berdampak buruk baginya. Walaupun memiliki keterbatasan dalam menggunakan sebaiknya mencegah daripada nanti kecanduan.

Sebenarnya media sosial itu sendiri sangat bermanfaaat bagi penggunanya, apabila peserta didik mendapatkan peningkatan prestasi dikarenakan sering menggunakan media sosial untuk keperluan positif. Namun sebaliknya kalau untuk keperluan negatif yang ada peserta didik akan mendapatkan cacian atau ungkapan kemarahan dari orangtua karena dilaporkan peserta didik tersebut mendapatkan banyak nilai merah dan yang biasanya dapat peringkat 10 besar malah keluar dari zona tersebut.

Jika hal itu sudah terjadi terus apa yang harus dilakukan seorang guru untuk meningkatkan prestasi peserta didik tanpa membuatnya terpengaruh hal-hal yag 
negatif. Yang dilakukan adalah setiap hari melakukan monitoring terhadap peserta didik, menjalin komunikasi yang baik dengan orangtua, selalu mendekati peserta didik yang tampak mencurigakan atau sedang memiliki masalah. Dengan seperti itu semoga keselarasan yang timbul dari peserta didik yang menggunakan media sosial dapat bermanfaat dengan sebaik-baiknya dan juga tidak mempengaruhi prestasi belajarnya di sekolah.

\section{SIMPULAN}

Penggunaan Media Sosial seperti instagram, facebook, twitter, youtube, whatsapp juga dapat mempengaruhi prestasi belajar peserta didik namun Hal tersebut tergantung pada tujuan dari masing-masing peserta didik, jika pengguna menggunakannya dengan positif maka akan berdampak baik terhadap prestasi belajar peserta didik, akan tetapi sebaliknya jika digunakan dengan sekedar mainmain dan tidak bisa membagi waktu untuk belajar maka kemungkinan besar akan berdampak buruk terhadap prestasi belajar siswa.

\section{DAFTAR PUSTAKA}

Fitri, Sulidar. (2017). Dampak Positif Dan Negatif Sosial Media Terhadap Perubahan Sosial Anak. Jurnal Kajian Penelitian Pendidikan dan Pembelajaran https://umtas.ac.id/journal/index.php/naturalistic/article/ download/5/14.

Laos, Aleksander. (2017). Prestasi Belajar Siswa. Surabaya: Kresna Bina Insan Prima.

Najamudin dkk. (2019). Sosial Media dan Prestasi Belajar: Studi Hubungan Penggunaan Facebook Terhadap Prestasi Belajar Siswa. Journal Pemikiran dan Penelitian Pendidikan http://journal.uinmataram.ac.id/index.php/tatsqif .

Permata, Sari dkk. (2019). Pengaruh Intensitas Penggunaan Internet Terhadap Prestasi Belajar Siswa Di Sma Negeri 13 Kerinci. Journal Wahana Konseling https://jurnal.univpgri-palembang.ac.id/index.php/juang/article/ download/2647/2616.

Rahman, Jain. (2017). Pengaruh Media Sosial Bagi Proses Belajar Siswa. Journal https://kalsel.kemenag.go.id/files/file/artikelprakom/15162891659956.pdf .

Zed, Mestika. (2003). Metode Penelitian Kepustakaan. Jakarta: Yayasan Obor Indonesia. 